\title{
Examination of Attitudes, Views and Skills of Early Childhood Education Teacher Candidates on Science Education
}

\author{
Özge AYDIN ŞENGÜL ${ }^{1}$, H. Gözde ERTÜRK KARA ${ }^{2}$ \\ ${ }^{1}$ Assit.Prof. Dr., Dumlupınar University,ozgeaydin@gmail.com \\ ${ }^{2}$ Assit.Prof.Dr., Aksaray University,gozdeerturk@aksaray.edu.tr
}

DOI: http://dx.doi.org/10.14582/DUZGEF.709

\begin{abstract}
The aim of this study was to analyze the relationship between scientific process skills, attitudes toward science and science teaching and to uncover third and fourth class early childhood education (ECE) teacher candidates' views on science teaching. Mixed method research design was used in this study. Both of the quantitative and qualitative data was collected from the participants. The findings of the study showed that ECE teacher candidates' scientific process skills were at the medium level and their attitudes toward science and science teaching were positive. There was a significant difference at their scientific process skills and attitudes toward science teaching according to the high school they graduated from. The scientific process skills variable was a moderator and partly accounted for the relationship between attitudes toward science and attitudes toward science teaching. Findings gathered from interviews indicated that the future ECE teachers could state which outcomes and methods/technics they could use in early childhood science education, but they couldn't give comprehensive science activity examples.
\end{abstract}

Keywords: early childhood, science education, scientific process skills, attitudes toward science, attitudes toward science teaching.

\section{Okul Öncesi Eğitimi Öğretmen Adaylarının Fen Eğitimine Yönelik Tutum, Görüş ve Becerilerinin İncelenmesi}

\section{ÖZ}

Araştırmanın amacı, okul öncesi eğitimi öğretmen adaylarının fen eğitimine ilişkin görüşlerini belirlemek, bilimsel süreç becerileri ile fene ve fen öğretimine yönelik tutumları arasındaki ilișkivi ortava koymaktır. Araștırmada, hem nicel hem nitel araştırma yöntemlerini barındıran karma yöntem araştırma deseni kullanılmıştır. Bulgular, öğretmen adaylarının bilimsel süreç becerilerinin orta düzeyde, fene ve fen öğretimine ilișkin tutumlarının ise olumlu olduğunu göstermiștir. Öğretmen adaylarının bilimsel süreç becerileri ve fen öğretimine ilişkin tutumları mezun oldukları lise türüne göre farkllılı göstermektedir. Bilimsel süreç becerileri değişkeni, bir moderator görevi görerek, öğretmen adaylarının fene ve fen öğretimine yönelik tutumları arasındaki ilişkinin bir bölümünü açıklamıştır. Görüşlerden elde edilen bulgular sonucunda ise, geleceğin okul öncesi öğretmenlerinin okul öncesi dönemde fen eğitiminde kullanılabilecek yöntemleri ve kazanımları bildikleri ancak kapsamlı bir etkinlik örneği sunamadıkları görülmüştür.

Anahtar Kelimeler: okul öncesi, fen eğitimi, bilimsel süreç becerileri, fene yönelik tutum, fen öğretimine yönelik tutum

\section{INTRODUCTION}

Studies on science teaching in early childhood period reveal that science education at this level mostly attempts to provide the children with basic life skills and skills of research, analysis, observation and developing cause-effect relations. Children attending pre-school institutions in Turkey usually have fewer opportunities to learn science than any other content area due to the limited science and pedagogical content knowledge of ECE teachers and teachers' low self-confidence for teaching young children science. ECE teachers play a vital role in providing rich and effective science learning experiences for children. Science methods courses, which typically are completed in the third year of undergraduate education in teaching training institutions, provide a major opportunity for ECE teacher candidates to develop their science content 
knowledge and knowledge of effective instructional practices for helping young children learn foundational science content and develop their science process skills (Batı et al., 2010; Saçkes et al., 2012).

Standards of science education (NRC, 1996) indicate that the skills of scientific process are very significant in science education. Lind (2000) defines these skills as those that people employ in constructing knowledge, thinking about problems and formulating solutions. Martin (2001) divides the skills of scientific process into two subcategories, namely basic process skills and integrated process skills. The first one includes observation, categorization, recording data, measuring, employing spatial/temporal relationships, using numbers, deriving conclusions and making estimations. Integrated process skills are much more complex than basic process skills and are consisted of manipulating, checking and interpreting variables, developing hypotheses, defining procedures, developing models and making experiments. Basic process skills are the prerequisite for integrated process skills.

One of the major objectives of early childhood science education is to provide an educational setting to allow children to monitor, review, categorize, estimate and experiment. Pre-school teachers should employ scientific process skills and also, be aware of the ways to teach these skills to children (Inan, 2011). In order to provide high-quality pre-school science education teachers' content and pedagogical knowledge as well as their attitudes toward science play very significant role (İnan, 2010; Akman, 2003; Tan \& Temiz, 2003). Only recently has interest been directed to how attitudes toward science affect learning and science teaching. Osborne (2003) describes attitudes toward science as "feelings, beliefs, and values held about an object that may be enterprise of science, school science and the impact of science on society or scientist themselves". Manning et al. (1982) stated "highly significant relationships exist between teachers' preparation and their practice and attitudes toward science". An explanation for the relationship between low science knowledge and reluctance to teach science was offered by Victor (1961), who found that teachers fear a loss of classroom prestige while providing science instruction. Fishbein and Ajzen (1975) described the relationship between beliefs, attitudes and behaviors (intended or actual). Any attitude change must also deal with belief change and behavior change. If someone's attitudes toward science changes, this change will be the same as the change in beliefs on science and science related behavior. The science education in early childhood period has a critical role in having positive attitude toward science and gaining basic scientific process skills in early years. From this point of view, it is expected from teacher candidates to know how to offer qualified science education in preschool.

\section{METHOD}

The aim of this study is to examine the relationship between ECE teacher candidates' scientific process skills and attitudes toward science and science teaching. It is also aimed to gain information about their views on science education. So, mixed method research design is used in this study. Research questions are;

1. What is the level of ECE teacher candidates' scientific process skills knowledge?

2. What is the attitude of ECE teacher candidates' toward science and science teaching?

3. Does gender make a significant difference in ECE teacher candidates' scientific process skills, attitudes toward science and attitudes toward science teaching?

4. Do the departments of high school which ECE teacher candidates' graduated from make a significant difference on their scientific process skills, attitudes toward science and attitudes toward science teaching?

5. Is there any significant relationship between ECE teacher candidates' attitudes toward science and attitudes toward science teaching when their scientific process skills are controlled?

6. What are ECE teacher candidates' views on science education in early childhood period?

\subsection{Participants}

The participants of the study are 80 third and fourth class ECE teacher candidates who are studying at Kastamonu University, Turkey. The students who took Science Education in Early Childhood course were chosen 
as participants. Also, eight students (five girls and three boys) were selected based on voluntariness for the interview.

Table 1. Demographic features of ECE teacher candidates

\begin{tabular}{lllll}
\hline Variables & & f & \% & Total \\
\hline \multirow{2}{*}{ Gender } & Female & 69 & 86,2 & 80 \\
& Male & 11 & 13,8 & \\
Department of & Math/ Science & 47 & 58,8 & \\
High School & Math /Language & 28 & 35 & 80 \\
& Social Studies & 5 & 6,2 &
\end{tabular}

Table 1 shows that $86,2 \%$ of sample are females and 13,8\% of sample are males. Turkish students attend high school before they study at universities. There are departments which have different types of courses in high schools. To learn about the background of the ECE teacher candidates, they were asked which department they graduated from. It is determined that 58,8 \% of sample were graduated from math/ science department , $35 \%$ of sample were graduated from math /language department and $6,2 \%$ of sample were graduated from social studies department.

\subsection{Data Collection Tools}

Scientific Process Skills Test: This test is used to search out the ability to solve the problems, which seem to be conflictual for teacher candidates when they teach science and mathematics. It is developed by Okey, Wise \& Burns (1982) to assess teacher candidates' scientific process skills and adapted by Geban, Aşkar and Özkan (1992) into Turkish. The test is consisted of 36 multiple-choice items all of which have four choices. The test has a high validity and its consistency is found to be .82 (KR 21). The items measure the abilities such as controlling variables, defining operationally, formulating hypotheses, interpreting data, experimenting and formulating models.

Attitude toward Science Teaching Scale (FÖYTÖ); This scale is developed by Thompson \& Shrigley in 1986 to examine elementary teachers' attitudes toward science teaching. Cho, Kim and Choi (2003) adapted it into ECE teacher candidates, and then Çakmak Çamlıbel (2012) adapted it into Turkish. It is a 5 point likert-type scale. Each item in the scale is assessed according to these statements; "certainly agree" (5), "agree" (4), "not sure" (3), "don't agree" (2) and "certainly don't agree" (1). According to confirmatory factor analyses, there are 17 items in the Turkish version of the scale. Participants gain 5 points for each positive item. The total score is 85 . The reliability coefficient alpha of the scale is found to be .81 . The alpha values change across the sub dimensions: "Comfortable-uncomfortable" .66, "Preparation before teaching" .75, "Hands on activity method".52 and "Developmental appropriateness". 46.

Attitude toward Science Scale: This scale is developed by Geban, Ertepınar, Yılmaz, Atlan \& Şahpaz in 1994 to assess ECE teacher candidates' attitudes toward science. It includes 15 items which are positive and negative. The total score is 75 and the reliability co-efficient alpha of this 5 point likert scale is 83 .

Interview Questions: Semi-structured interview form that includes three questions was prepared in order to determine the opinions of candidate teachers about science education and science activities. Those questions were developed by the help of related literature and the experiences of the researchers. While preparing the questions, researchers appealed to three specialists in the fields of assessment and evaluation, science education and early childhood education and then reorganized the questions in the light of their reviews. The "Interview Protocol" is given in appendix.

\subsection{Data Analysis}

In the research, both quantitative and qualitative research methods were used. The quantitative data were obtained by the "Scientific Process Skills Test", "Attitude toward Science Teaching Scale", and "Attitude toward Science Scale". The quantitative data were obtained by the "semi-structured interview form". For the analysis of quantitative data; mean and standard deviation values were calculated to determine ECE teacher candidates' scientific process skills, their attitudes toward science and their attitudes toward science teaching. 
Multivariate analysis of variance (MANOVA) is used to investigate the effect of two independent variables on dependent variables. MANOVA is a statistical test procedure for comparing multivariate (population) means of several groups. Unlike ANOVA, it uses the variance-covariance between variables in testing the statistical significance of the mean differences. (Büyüköztürk, 2009). In this study; dependent variables are scientific process skills, attitude toward science and attitude toward science teaching variables. Independent variables are gender and department of high school from which the participants graduated. Also, partial correlation analysis was done to investigate the relationship between teacher candidates' attitude toward science and their attitudes toward science teaching by controlling their scientific process skills. Partial correlation provides an opportunity to calculate the relationship between two variables by controlling one or more variable. The relationship between two variables can be originated from themselves or it can be originated from one or more variables which is/are related to this relationship (Büyüköztürk, 2009).

For the interviews, three questions related to the science education and science activities were asked to eight ECE teacher candidates. The interviews were lasted approximately 12-18 minutes. The interviews were recorded with the permission of the students. At the first level of the data analysis, these records have been listened to and read several times by the researchers. The data were obtained and significant parts were identified. Then the code list was developed. The data coding period generally requires researcher to read data set several times and study on codes again and again (Yıldırım and Şimşek, 2008). In the light of code list, themes were identified explaining the data in general and obtaining the codes under specific categories. The data were described; tabs were developed and interpreted systematically according to the codes and themes. To help with the reliability of the coding, another researcher also coded a subset of the data for the triangulation. This researcher has a study experience in both science and early child education. All coding was done independently and separately. It was found that interrater reliability value is 0,89 and it is thought that this value is enough for interrater reliability. Flick (2011) describes this type of triangulation as "investigator triangulation". Investigator triangulation can be used when it is necessary to include more than one researcher in the study process. Creswell (2007) argues that investigator triangulation in qualitative research validation strategies provides corroborating evidence.

\section{FINDINGS}

\subsection{Analysis of Quantitative Findings}

The mean and standard deviation values were identified to examine the test and scale scores of the participants.

Table 2. Mean and standard deviation of test and scales

\begin{tabular}{llll}
\hline Data collection tools & $\bar{X}$ & sd & $\mathrm{N}$ \\
\hline Scientific Process Skills Test (SPS) & 21,06 & 4,99 & \\
Attitude Toward Science Teaching Scale (ASTS) & 62,98 & 7,56 & \multirow{2}{*}{80} \\
Attitude Toward Science Scale (ASS) & 46,61 & 10,40 & \\
\hline
\end{tabular}

Table 2 indicates that the participants' mean score in the scientific process skills test is 21.06; it is is 62.98 in the scale of attitudes toward science teaching and 46.61 in the attitude toward science scale. Given that the maximum score of SPS is 36, that of ASTS is 85 and that of ASS is 75, it can be argued that ECE teacher candidates' scientific process skills knowledge is at the medium level and their attitudes toward science and science teaching are positive.

In the study; multivariate analyses of variance (MANOVA) is used to investigate the effect of two independent variables on dependent variables. The data was examined whether it showed normal distribution or not. Because the coefficient of skewness of the data is between -1 and +1 , showing that it is distributed normally. One of the prerequisite for multivariate analyses of variance is the homogeneity of variancecovariance matrices. Box's M statistical values are examined for this purpose. 
Table 3. Box-M table

\begin{tabular}{ll}
\multicolumn{2}{l}{ Table 3. Box-M table } \\
\hline Box's M & 27,767 \\
F & 1,284 \\
df1 & 18 \\
df2 & 981,327 \\
Sig. &, 190 \\
\hline
\end{tabular}

When the level of significance is agreed at 0.01 , following hypothesis are written.

H0: Variance-covariance matrices are equal.

H1: Variance-covariance matrices are not equal.

The sig. value (0.19) is higher than 0.01 , then H0 hypothesis is agreed. Variance-covariance matrices are equal. Although a Box-M test analysis is adequate, the Levene's test is also used to examine the variances of independent variables independently. Table 4 shows the valued of Levene's test.

Table 4. Values of levene's test

\begin{tabular}{lllll}
\hline Measures & F & df1 & df2 & Sig. \\
\hline Scientific Process Skills Test &, 863 & 4 & 75 &, 490 \\
Attitude Toward Science Teaching Scale &, 566 & 4 & 75 &, 688 \\
Attitude Toward Science Scale & 2,185 & 4 & 75 &, 079
\end{tabular}

Because sig. values are higher than 0.01 , the analyses process is continued.

Multivariate tests were carried following the processes above. According to Kalayc1 (2006) the Wilks' Lambda values are generally considered on multivariate tests. When the values are examined in Table 5 , the effect of gender and department of high school variables on scientific process skills knowledge, attitudes toward science and science teaching can be seen clearly.

Table 5. Values of multivariate tests (c)

\begin{tabular}{|c|c|c|c|c|c|c|c|}
\hline Effect & & Value & $\mathbf{F}$ & $\begin{array}{l}\text { Hypothesis } \\
\text { df }\end{array}$ & Error df & Sig. & $\begin{array}{l}\text { Partial } \\
\text { Eta } \\
\text { Squared }\end{array}$ \\
\hline \multirow{5}{*}{ Gender } & Pillai's Trace & 083 & $2,207(\mathrm{a})$ & 3,000 & 73,000 & ,094 & , 083 \\
\hline & $\begin{array}{l}\text { Wilks' } \\
\text { Lambda }\end{array}$ & ,917 & 2,207(a) & 3,000 & 73,000 & ,094 & ,083 \\
\hline & $\begin{array}{l}\text { Hotelling's } \\
\text { Trace }\end{array}$ & ,091 & 2,207(a) & 3,000 & 73,000 & ,094 & 083 \\
\hline & $\begin{array}{l}\text { Roy's Largest } \\
\text { Root }\end{array}$ & ,091 & 2,207(a) & 3,000 & 73,000 & ,094 & ,083 \\
\hline & Pillai's Trace & ,204 & 2,808 & 6,000 & 148,000 & ,013 &, 102 \\
\hline \multirow{4}{*}{ Courses in High School } & $\begin{array}{l}\text { Wilks' } \\
\text { Lambda }\end{array}$ &, 798 & 2,904(a) & 6,000 & 146,000 & ,011 & ,107 \\
\hline & $\begin{array}{l}\text { Hotelling's } \\
\text { Trace }\end{array}$ & ,250 & 2,997 & 6,000 & 144,000 & ,009 & ,111 \\
\hline & $\begin{array}{l}\text { Roy's Largest } \\
\text { Root }\end{array}$ & ,236 & $5,833(\mathrm{~b})$ & 3,000 & 74,000 & ,001 & ,191 \\
\hline & Pillai's Trace & ,070 & 1,822(a) & 3,000 & 73,000 & ,151 &, 070 \\
\hline \multirow{3}{*}{$\begin{array}{l}\text { Gender * Courses in High } \\
\text { School }\end{array}$} & $\begin{array}{l}\text { Wilks' } \\
\text { Lambda }\end{array}$ & ,930 & $1,822(a)$ & 3,000 & 73,000 & ,151 & ,070 \\
\hline & $\begin{array}{l}\text { Hotelling's } \\
\text { Trace }\end{array}$ & 075 & 1,822(a) & 3,000 & 73,000 & ,151 & ,070 \\
\hline & $\begin{array}{l}\text { Roy's Largest } \\
\text { Root }\end{array}$ & ,075 & $1,822(a)$ & 3,000 & 73,000 & ,151 & ,070 \\
\hline
\end{tabular}

\section{a Exact statistic}

$\mathrm{b}$ The statistic is an upper bound on $\mathrm{F}$ that yields a lower bound on the significance level.

c Design: Intercept+gender+department of high school+gender * department of high school.

The significant values are considered to examine the effect of gender and department of high school on dependent variables in Table 5. The sig. value for gender is .094 (Wilks Lambda). Because this value is higher than 0.01 , it is not significant. Because the sig. value of high school department is .011, it is significant. Also, the interaction between gender and department of high school (gender* department of high school) does not have a significant effect on dependent variables. The hypotheses were stated such as; for gender; Ho: there is no significant difference between means according to gender, H1: there is a significant difference between 
means according to gender. Because sig. value is .094, Ho is agreed. There is no significant difference between means: This statement means that there is no significant difference on ECE teacher candidates' scientific process skills, attitude toward science and science teaching according to gender. For department of high school; Ho: there is no significant difference between means according to the department of high school. H1: there is a significant difference between means according to the department of high school. Because sig. value is .011, Ho is not agreed. There is a significant difference between means. This statement means that there is a significant difference on ECE teacher candidates' scientific process skills, their attitudes toward science and science teaching according to the department of high school. For the interaction of gender and the department of high school variables; Ho: there is no significant difference between means. H1: there is a significant difference between means. Because sig. value is .151, Ho is agreed. There is no significant difference between means: This statement means that the interaction of gender and department of high school is not significant.

Tablo 6. Variance analyses (tests of between-subjects effects)

\begin{tabular}{|c|c|c|c|c|c|c|c|}
\hline Source & $\begin{array}{l}\text { Dependent } \\
\text { Variable }\end{array}$ & $\begin{array}{l}\text { TypeIII Sum of } \\
\text { Squares }\end{array}$ & Df & Mean Square & $\mathrm{F}$ & Sig. & $\begin{array}{l}\text { Partial } \\
\text { Eta } \\
\text { Squared }\end{array}$ \\
\hline & SPS & 393,175 (a) & 4 & 98,294 & 4,679 & ,002 & ,200 \\
\hline & ASTS & $1035,312(b)$ & 4 & 258,828 & 5,587 & ,001 & ,230 \\
\hline \multirow[t]{3}{*}{ Model } & ASS & $559,271(\mathrm{c})$ & 4 & 139,818 & 1,313 & ,273 &, 065 \\
\hline & SPS & 26,968 & 1 & 26,968 & 1,284 & ,261 &, 017 \\
\hline & ASTS & 38,326 & 1 & 38,326 & ,827 &, 366 & ,011 \\
\hline \multirow[t]{4}{*}{ Gender } & ASS & & & & & & \\
\hline & & ,301 & 1 & ,301 & ,003 & ,958 &, 000 \\
\hline & SPS & 368.272 & 2 & 184,136 & 8,766 & ,000 & , 189 \\
\hline & ASTS & 490,443 & 2 & 245,221 & 5,293 &, 007 & ,124 \\
\hline \multirow[t]{2}{*}{$\begin{array}{l}\text { Department } \\
\text { of High } \\
\text { School }\end{array}$} & ASS & 419,522 & 2 & 209,761 & 1,970 & ,147 & ,050 \\
\hline & SPS & 29,687 & 1 & 29,687 & 1,413 &, 238 &, 018 \\
\hline \multirow{4}{*}{$\begin{array}{l}\text { Gender* } \\
\text { Department } \\
\text { of } \\
\text { High } \\
\text { School }\end{array}$} & ASTS & 19,204 & 1 & 19,204 & ,415 &, 522 &, 005 \\
\hline & ASS & ,118 & 1 & ,118 & ,001 & 974 &, 000 \\
\hline & SPS & 1575,512 & 75 & 21,007 & & & \\
\hline & ASTS & 3474,638 & 75 & 46,329 & & & \\
\hline \multirow[t]{3}{*}{ Error } & ASS & 7985,716 & 75 & 106,476 & & & \\
\hline & SPS & 37459,000 & 80 & & & & \\
\hline & ASTS & 321778,000 & 80 & & & & \\
\hline Total & ASS & 182363,000 & 80 & & & & \\
\hline
\end{tabular}

a R Squared $=$,200 (Adjusted R Squared $=, 157$ )

$\mathrm{b}$ R Squared $=, 230$ (Adjusted R Squared $=, 188)$

c R Squared $=, 065$ (Adjusted R Squared $=, 016$ ) 
Table 6 shows that only the variable of the high school department has a significant effect on ECE teacher candidates' scientific process skills and their attitudes toward science teaching. But it has no significant effect on ECE teacher candidates' attitudes toward science. Only the variable of high school department has a sig. value lower than .01 . And also, it is seen that the department of high school variable has more effect on scientific process skills according to PES (Partial Eta Squared) values.

Because there is a significant difference, multiple comparisons tables were created for the department of high school variable. Multiple Comparisons Tables (Post Hoc) show ECE teacher candidates' scientific process skills (Table 7) and their attitudes toward science teaching (Table 8) according to the department of high school.

Table 7: Participants' scientific process skills based on department of high school

\begin{tabular}{lllll}
\hline & Department of & N & Subset & \\
\cline { 3 - 4 } & High School & & 2 & 1 \\
\hline \multirow{3}{*}{ Tukey HSD(a,b) } & Language & 5 & 13,4000 & 20,5357 \\
& Math/ Language & 28 & & 22,1915 \\
& Math/Science & 47 & &, 659 \\
\hline
\end{tabular}

Means for groups in homogeneous subsets are displayed.

Based on Type III Sum of Squares

The error term is Mean Square (Error) $=21,007$.

a Uses Harmonic Mean Sample Size $=11,674$.

b Alpha $=, 05$.

Table 7 shows ECE teacher candidates' mean scores in regard to the scientific process skills. It is seen that ECE teacher candidates who were graduated from math/science department in high school have highest mean scores than the others.

Table 8: Participants' attitudes toward science teaching based the department of high school

\begin{tabular}{|c|c|c|c|c|}
\hline & \multirow{2}{*}{$\begin{array}{l}\text { Department of } \\
\text { High School }\end{array}$} & \multirow[t]{2}{*}{$\mathbf{N}$} & \multicolumn{2}{|l|}{ Subset } \\
\hline & & & 2 & 1 \\
\hline & Language & 5 & 52,8000 & \\
\hline \multirow[t]{3}{*}{ Tukey HSD $(a, b)$} & Math/ Language & 28 & & 60,5000 \\
\hline & Math/Science & 47 & & 65,5319 \\
\hline & Sig. & & 1,000 & 181 \\
\hline
\end{tabular}

Means for groups in homogeneous subsets are displayed.

Based on Type III Sum of Squares

The error term is Mean Square (Error) $=46,329$.

a Uses Harmonic Mean Sample Size $=11,674$.

b Alpha $=, 05$.

Table 8 shows ECE teacher candidates' attitude toward science teaching. It is seen that those participants who were graduated from math/science department in high school have more positive attitudes toward science teaching than the others.

The relationship between attitude toward science (ASS) and attitude toward science teaching (ASTS) was tested with partial correlation analysis by controlling the scientific process skills variable. The purpose of this analysis is to determine the effect of scientific process skills (which was thought to be related) on the relationship between attitudes toward science and attitudes toward science teaching. 
Table 9. Partial correlation analyses

\begin{tabular}{|c|c|c|c|c|c|}
\hline Control Variables & & & AS & AST & SPS \\
\hline \multirow{8}{*}{-none-(a) } & ASS & & & & \\
\hline & & Correlation & 1,000 & ,422 & ,492 \\
\hline & & $\begin{array}{l}\text { Significance } \\
\text { (2-tailed) }\end{array}$ & . & 000 &, 000 \\
\hline & & df & 0 & 78 & 78 \\
\hline & ASTS & & & & \\
\hline & & Correlation & ,422 & 1,000 & ,716 \\
\hline & & & ,000 & . & ,000 \\
\hline & & df & 78 & 0 & 78 \\
\hline \multirow[t]{12}{*}{ SPS } & SPS & & & & \\
\hline & & Correlation & , 492 &, 716 & 1,000 \\
\hline & & $\begin{array}{l}\text { Significance } \\
\text { (2-tailed) }\end{array}$ & ,000 &, 000 & . \\
\hline & & df & 78 & 78 & 0 \\
\hline & ASS & & & & \\
\hline & & Correlation & 1,000 & ,114 & \\
\hline & & $\begin{array}{l}\text { Significance } \\
\text { (2-tailed) }\end{array}$ & . &, 317 & \\
\hline & & df & 0 & 77 & \\
\hline & ASTS & & & & \\
\hline & & Correlation & ,114 & 1,000 & \\
\hline & & $\begin{array}{l}\text { Significance } \\
\text { (2-tailed) }\end{array}$ & ,317 & . & \\
\hline & & $\mathrm{df}$ & 77 & 0 & \\
\hline
\end{tabular}

a. Cells contain zero-order (Pearson) correlations.

Table 9 shows that the correlation coefficient is .422 between ECE teacher candidates' attitudes toward science (ASS) and their attitudes toward science teaching (ASTS). When scientific process skills variable (SPS) has a role of moderator in the analysis; it is seen that the correlation coefficient decreases to .114 . This analysis shows that ECE teacher candidates' scientific process skills can be thought as a moderator on the relationship between their attitudes toward science and their attitudes toward science teaching and it partially accounts for this relationship.

\subsection{Findings of Qualitative Analysis}

\subsubsection{Interview Analysis}

In the analysis of the interviews, the following themes and codes are used and they are given in Table 10.

Table10. Themes and codes

\begin{tabular}{|c|c|}
\hline Themes & Codes \\
\hline \multirow{13}{*}{ Outcomes related to Science Education } & Environment \\
\hline & Creatures \\
\hline & Natural Events \\
\hline & Accidents and dangers \\
\hline & Problem solving skills \\
\hline & Health \\
\hline & Cleaning \\
\hline & Disease \\
\hline & Technology \\
\hline & Material \\
\hline & Seasons \\
\hline & Day/Night \\
\hline & Daily Life \\
\hline \multirow{11}{*}{ Methods/ Techniques used in Science Activities } & Experiment \\
\hline & Trip \\
\hline & Question- Answer \\
\hline & Play \\
\hline & Demonstration \\
\hline & Project \\
\hline & Analogy \\
\hline & Drama \\
\hline & Case study \\
\hline & Discussion \\
\hline & Expression \\
\hline
\end{tabular}




\begin{tabular}{ll}
\hline & Recycling \\
& Bean germination \\
& Form of rain and snow \\
& Arbor \\
Science Activities & Candle experiment \\
& Form model of earth \\
& The effect of air on matters \\
State of matter & Fingerprint \\
& Form of rainbow \\
& Grass man \\
\hline
\end{tabular}

As a result of the analysis of the interviews, three different themes were found by two different researchers. Analyzing the data, researchers defined the information presented by the participants more frequently and they decided the themes together. Those themes identified were outcomes they use to plan science activities, methods/ techniques used in science activities and science activities.

Outcomes they use to plan science activities: ECE teacher candidates indicated that they prefer to use outcomes related to environment, creatures, natural events, accidents and dangers, problem solving skills, health, cleaning, disease, technology, material, seasons, day/night and daily life. The examples they gave related to this theme are as follows: Students "can recognize the environment and protect it", "can take care of an animal or a plant", "can collect general information about living things", "can understand the relationship between living things and environment", can "be aware of the natural events", "can protect himself against accidents", "can solve problems", "can distinguish living and nonliving things", "can prefer to eat healthy food and can be clean", "know how to protect themselves against diseases. "Know what are the technological tools used for and know how to use them", "learn the seasons", "can use information about science in daily life" and "observe the growth of animals and plants".

Methods/ techniques used in science activities: ECE teacher candidates indicated that they prefer to use methods/technics such as experiment, trip, question- answer, play, demonstration, project, analogy, drama, case study, discussion and expression. The examples they gave related to this theme are as follows; "Children can learn science by doing experiments". "Teachers can plan trips and provide opportunities with children to observe new places and new materials", "Play and art activities can be planned about science issues", "children can make a product and present it to their friends with the help of the instructions that teacher gives them".

Science activities: ECE teacher candidates indicated that they prefer to do science activities such as recycling, bean germination, form of rain and snow, arbor, candle experiment, form model of earth, the effect of air on matters, state of matter, fingerprint, form of rainbow, grass man. The examples they gave related to this theme are as follows; "making rainbow: we use a lamb and crystal glasses. When you turn on the lamb in a dark place, the colors of rainbow are reflected on the walls and rainbow occurs", "the impact of air on materials: we put raisins to the soda water. Raisins start to swim up and down in it. So children can observe the impact of bubbles on raisins", "making an earth model: we form a ball as an earth. Children paint some parts of it with blue and brown color. Then, earth model occurs and we present it in science center of class", "candle activity: we use a candle and a glass for this experiment. We close the glass into the candle and children can observe how it is blowed out and we discuss why this happened", "bean germination: We put cotton in to the plastic glasses and add some bean seed on it. Then we close it with the help of a small piece of cotton. Then, we place it near window so that it can get sun light and children water it every day. They observe how it grows day by day".

\section{DISCUSSION and RESULTS}

Those research questions were examined in the first part of the study are as follows; 1) What is the level of ECE teacher candidates' scientific process skills knowledge?, 2) What is the attitude of ECE teacher candidates' toward science and science teaching?, 3) Does gender make a significant difference on ECE teacher candidates' scientific process skills, attitudes toward science and attitudes toward science teaching?, 4) Do the departments of high school which ECE teacher candidates' graduated from make a significant 
difference on their scientific process skills, attitudes toward science and attitudes toward science teaching?, 5) Is there any significant relationship between ECE teacher candidates' attitudes toward science and attitudes toward science teaching when their scientific process skills are controlled? The analysis indicates that ECE teacher candidates' knowledge about scientific process skills is in medium level and their attitudes toward science and science teaching are positive. Çakmak Çamlıbel (2012) found that the knowledge level of the ECE teacher candidates' in regard to science concepts is at the levels of medium or higher. Findings from many studies support the finding that ECE teacher candidates have a positive attitude toward science and science teaching (Sönmez, 2007; Timur, 2012 \& Sansar, 2010). Although the participants took only one sciencerelated course during their undergraduate studies, their attitudes toward science are positive. The reason for this can be that the content offered in this course reinforced their knowledge level and attitude positively or their past experience in science was enough (Çakmak Çamlıbel, 2012). It can also be argued that when the attitudes of ECE teachers toward science increase, the frequency of the science activities provided for children increase. Sönmez (2007) stated that there was a significant correlation between the total score of ECE teachers' attitudes toward science and the total score of the frequency of science activities provided in the classroom. It was also reported that the scientific process skills, attitudes toward science and science education of teacher candidates do not vary according to their gender. Therefore, female and male teacher candidates' skills of scientific process do not differ significantly (Temiz, 2001; Chin, 2005).

On the other hand, the department of high school was found to have significant effects on teacher candidates' scientific process skills and attitudes toward science education. However, it was found that this variable does not have any significant effect on attitudes toward science. Doğruöz (1998) concluded that those teacher candidates who took education based on scientific process skills had higher levels of interest in science and of attitudes toward science.

It was found that those teacher candidates who are the graduates of math/science departments at high schools have the highest level of both scientific process skills and attitudes toward science, while those who are the graduates of language department have the lowest level of both scientific process skills and attitudes toward science. Ekinci Vural and Hamurcu (2008) also concluded that teacher candidates who are the graduates of math/science department at high schools have much more positive attitudes toward science education in contrast to those who are the graduates of language department.

It was reported that scientific process skills of ECE teacher candidates is the mediator between their attitudes toward science and their attitudes toward science education and that their scientific process skills partially accounts for the relationship between their attitudes toward science and their attitudes toward science education. It is for this reason that teacher candidates should have sufficient content knowledge in science in order to offer an effective science education (Kallery \& Psillos, 2001; Davies \& Howe, 2003). The relationship between level of science preparation, beliefs and attitudes toward science teaching has been shown to be positive in some studies (Crawley, 1991; Manning et al., 1982; Mechling et al., 1982), while other studies (Stepans \& McCormack, 1985; Feistritzer \& Boyer, 1983) found no relationship or even a negative relationship. Çakmak Çamlıbel (2012) analyzed the relationship between knowledge on science concepts and attitudes toward science and found that there is a statistically significant difference in the scores in the science concept test of those students who have lower levels of attitudes toward science and those who have higher levels of attitudes toward science. The same difference was also found between those who have higher levels of attitudes toward science and those who have medium levels of attitudes toward science. These findings clearly argue that the level of attitudes toward science affects the achievement of students in regard to science concepts. In the current study the teacher candidates' views about early childhood science education and activities. They articulated views about gains, methods/techniques, and activities. They stated that early childhood science education provides the students with the opportunity to gain views about environment, living beings, natural events, accidents and dangers, problem-solving skills, health-care, diseases, technology, 
seasons, and daily life. They reported that they can mostly make use of the following techniques and methods in early childhood science education: experiments, visits, observation, question-answer, demonstrations, project, analogy, drama, sample cases, discussion and lectures. They stated that the common activities in the courses can be related to recycling, occurrence of rain and snow, planting trees, developing an earth model, the effect of air on substances, finger print and occurrence of rainbow. It is seen that the participants focus on experiments as science activity. These findings are similar to those of Şahin (2000). Şahin (2000) concluded that most of the teacher candidates think that science education can only be carried out through experiments. It was also found that they employ mostly simple experiments and that they did not use concept maps. Karamustafaoğlu and Kandaz (2006) found that those methods and techniques mostly used by teachers in science education are lectures, dramas, using simple hand-made models, experiments, visit and observation, concept maps, analogies, and projects. Kildan and Pektaş (2009) concluded that teachers frequently employ the following methods and techniques in relation to science and nature: visits, observations, experiments, projects, drama, educative toys, TV and video and computer-assisted teaching. Inan (2011) found that ECE teachers can provide examples for their planning of each scientific process skills. Hamurcu (2006) found that for ECE teacher candidates' environmental awareness through science education and active participation of students in science education are significant.

\section{RECOMMENDATIONS}

Based on the findings obtained in the study the following suggestions were developed. In the study it is found that although the participants' attitudes toward both science and science education are positive and they have necessary knowledge about potential gains in science education, they could not develop plans for effective activities. Therefore, they should be offered necessary opportunity to practice in regard to activities to be used in early childhood science education. Given that scientific process skills are significant these skills of teacher candidates can be improved in teacher training programs. Their knowledge on scientific concepts should also be improved in their undergraduate studies

\section{REFERENCES}

Akman, B., Üstün, E. \& Güler, T. (2003). 6 Yaş Çocuklarının Bilim Süreçlerini Kullanma Yetenekleri. Hacettepe Üniversitesi Eğitim Fakültesi Dergisi, 24, 11-14.

Bat1, K., Ertürk, G. \& Kaptan, F.(2010). The Awareness Levels of Pre-School Education Teachers Regarding Science Process Skills. Procedia Social and Behavioral Sciences, 2, 1993-1999.

Büyüköztürk, Ş. (2009). Sosyal Bilimler İ̧̧in Veri Analiz̧i El Kitabı. Ankara: Pegem Akademi Yayıncılık.

Chin, C. (2005). First-year Pre-service Teachers in Taiwan-Do They Enter the Teacher Program with Satisfactory Scientific Literacy and Attitudes toward Science? International Journal of Science Education, 27(13), 1549-1570.

Cho, H., Kim, J. \& Choi, D. H. (2003). Early Childhood Teachers' Attitudes toward Science Teaching: A Scale Validation Study, Educational Reseach Quarterly. 27(2),33-42.

Creswell, J. W. (2007). Educational research: planning, conducting, and evaluating quantitative and qualitative research. (3rd Ed.). Thousands Oaks, CA: Sage.

Crawley, N. N. (1991). The Summary of Research in Science Education - 1989. Science Education, 75(3), 1-35.

Çamlıbel Çakmak, Ö. (2012). Okul Öncesi Öğretmen Adaylarının Fen Öğretime Yönelik Tutumları ile Bazı Fen Kavramlarını Anlama Düzeyleri Arasındaki İlişkinin İncelenmesi. Türk Fen Eğitimi Dergisi, 9 (3), $40-51$.

Davies, D. \& Howe, A. (2003). Teaching science and design and technology in the early years, London, David Fulton Publishers.

Doğruöz, P. (1998). "Bilimsel İșlem Becerilerini Kullanmaya Yönelik Yöntemin Öğrencilerin Akıșkanların Kaldırma Kuvveti Konusunu Anlamalarına Etkisi”.Yayınlanmamış Yüksek Lisans Tezi, Orta Doğu Teknik Üniversitesi, Ankara.

Ekinci Vural, D. \& Hamurcu, H. (2008). Preschool Teacher Candidates' Self-Efficacy Beliefs Regarding Science Teaching Lesson and Opinions about Science. Elementary Education Online, 7(2), 456-467.

Feistritzer, E. C., \& Boyer, E. L. (1983). The conditions of teaching: A state by state analysis. The Carnegie Foundation for the Advancement of Teaching, Princeton, New Jersey. 
Fishbein, M., \& Ajzen, L. (1975). Belief, attitude, intention, and behavior, reading. MA: Addison-Wesley.

Flick, U. (2011). Triangulation-eine einführung. Wiesbaden: VS Verlag.

Geban, Ö., Aşkar, P. \& Özkan, İ. (1992). Effects of Computer Simulation and Problem Solving Approaches on High School. Journal of Educational Research. 86 (1), 5-10.

Geban, Ö., Ertepınar, H., Yılmaz, G., Atlan, A. \& Şahpaz, Ö. (15-17 Eylül 1994). Bilgisayar Destekli Eğitimin Ögrencilerin Fen Bilgisi Başarlarna ve Fen Bilgisi Illgilerine Etkisi. I. Ulusal Fen Bilimleri Eğitimi Sempozyumunda sunulmuş bildiri, İzmir.

Hamurcu, H. (07- 09 Eylül 2006). Okul Öncesi Ögretmen Adaylarmm Fen Ögrretimi Hakekndaki Görüsleri. 7. Ulusal Fen Bilimleri ve Matematik Eğitimi Kongresinde sunulmuş bildiri, Ankara.

İnan, Z. (2010). Okul Öncesi Öğretmen Adaylarının Bilimsel Süreç Becerilerine İlişkin Alan Bilgileri ve Pedagojik Alan Bilgilerinin İrdelenmesi. Kuram ve Uygulamada Eğitim Bilimleri, 10 (4), 2275-2323.

Inan, H. Z. (2011). Teaching Science Process Skills in Kindergarten. Social and Educational Studies (Energy Education Science and Technology Part B), 3(1), 47-64.

Kalayc1, Ş. (2006). SPSS uygulamah çok değişkenli istatistik teknikleri. Ankara: Asil Yayın Dağıtım Ltd. Şirketi.

Kallery, M. \& Psillos, D. (2001). Pre-School Teachers' Content Knowledge in Science: Their Understanding of Elementary Science Concepts and of Issues Raised by Children's Questions. International Journal of Early Years Education. 9(3), 165-179.

Karamustafaoğlu, S. \& Kandaz, U. (2006) Okul Öncesi Eğitimde Fen Etkinliklerinde Kullanılan Öğretim Yöntemleri ve Karş1laş1lan Güçlükler GÜ, Gað̧i Eğitim Fakülttesi Dergisi. 26(1), 65-81

Kıldan, O. \& Pektaş, M. (2009). Erken Çocukluk Döneminde Fen ve Doğa İle İlgili Konuların Öğretilmesinde Okulöncesi Öğretmenlerinin Görüşlerinin Belirlenmesi Abi Evran Üniversitesi, Krrşehir Eğitim Fakültesi Dergisi, (KEFAD) 10(1), 113-127.

Lind, K. K. (2000). Exploring science in early childhood education (3rd.ed.). Albany: Delmar. Albany

Manning, P.C., Esler, W. K., \& Baird, J. R. (1982). How Much Elementary Science Is Really Being Taught?. Science and Children, 19(8), 40-41.

Mechling, D. R., Stedman, C. \& Donnellon, J. (1982). Preparing and Certifying Science Teachers: An NSTA Report. Science and Children, 20(2), 9-14.

Stepans, J., \& McCormack, A. (1985). A study of scientific conceptions and attitudes toward science of prospective elementary teachers: A research report. ERIC Document Reproduction Service No. ED 226024.

Martin (2001). Constructing early childhood science, Delmar Thomson Learning.

Okey, J. R., Wise, K. C. \& Burns, J. C. (1982). Integrated process skill test-2. (James R. Okey, Department of Science Education, University of Georgia, Athens, GA 30362, USA).

Yıldırım, A. \& Şimşek, H. (2008). Sosyal bilimlerde nitel araştırma yöntemleri. Ankara:Seçkin Yayıncılık.

Osborne, J. (2003). Attitudes toward Science: A Review of the Literature and Its Implications. International Journal of Science Education. 25, 9, 1049-1079.

Saçkes, M., Akman, B. \& Trundle, K. (2012). A Science Methods Course for Early Childhood Teachers: A Model for Undergraduate Pre-Service Teacher Education. Necatibey Eğitim Fakültesi Elektronik Fen ve Matematik. Eğitimi Dergisi (EFMED), 6(2), 1-26.

Şahin, F. (2000), Okulöncesinde Fen Bilgisi Öğretimi ve Aktivite Örnekleri, İstanbul: Ya-Pa Yayınları.

Stepans, J., \& McCormack, A. (1985). A study of scientific conceptions and attitudes toward science of prospective elementary teachers: A research report. ERIC Document Reproduction Service No. ED 226024.

Sönmez S. (2007). “Okul Öncesi Öğretmenlerinin Fen ve Fen Eğitimine Yönelik Tutumları” Yayınlanmamış Yüksek Lisans Tezi, Orta Doğu Teknik Üniversitesi Sosyal Bilimler Enstitüsü, Ankara.

Özbek S. (2009). "Okulöncesi Öğretmenlerinin Fen Eğitimine İlişkin Görüşleri ve Uygulamalarının İncelenmesi”, Yayınlanmamış Yüksek Lisans Tezi, Çukurova Üniversitesi Sosyal Bilimler Enstitüsü, Adana.

Tan, M. \& Temiz, K. (2003). Fen Öğretiminde Bilimsel Süreç Becerilerinin Yeri ve Önemi. Pamukkale Üniversitesi Ë̆itim Fakültesi Dergisi, 1(13), 89-101.

Temiz, B. K.(2001). "Lise 1. Sınıf Fizik Dersi Programının Öğrencilerin Bilimsel Süreç Becerilerini Geliştirmeye Uygunluğunun İncelenmesi”. Yayınlanmamış Yüksek Lisans Tezi. Gazi Üniversitesi, Ankara.

Timur, B. (2012). Determination of Factors Affecting Preschool Teacher Candidates' Attitudes toward Science Teaching. Educational Sciences: Theory \& Practice. Special Issue, 2997-3009.

\section{Citation Information}

Aydın Şengül, Ö. \& Ertürk Kara, H., G. (2016) Examination of Attitudes, Views and Skills of Early Childhood Education Teacher Candidates on Science Education. Dicle Üniversitesi Ziya Gökalp Eğitim Fakültesi Dergisi, 28, 163-174. 